\title{
ANALISIS KEMAMPUAN MULTI REPRESENTASI DAN KAITANNYA DENGAN PEMAHAMAN KONSEP FISIKA
}

\section{ANALYSIS OF MULTIPLE REPRESENTATION ABILITY AND THE RELATIONSHIP WITH THE CONCEPTUAL UNDERSTANDING OF PHYSICS}

\author{
Laily Yosie Kurniasari* dan Wasis \\ Program Studi Pendidikan Fisika Fakultas MIPA Universitas Negeri Surabaya, Surabaya, Indonesia \\ *Email: laili.17030184063@mhs.unesa.ac.id
}

Diterima: 18 Januari 2021. Disetujui: 1 Februari 2021. Dipublikasikan: 3 Maret 2021

\begin{abstract}
Abstrak: Penelitian ini bertujuan untuk menganalisis profil kemampuan multirepresentasi siswa SMA pada materi gerak lurus yang diukur menggunakan instrumen berbasis multi representasi, dan mendeskripsikan hubungan antara kemampuan multi representasi dengan pemahaman konsep siswa pada materi gerak lurus. Penelitian ini dilakukan pada siswa kelas XI IPA sebanyak 22 siswa di SMA Negeri 1 Sambit pada semester genap tahun pelajaran 2020/2021. Penelitian dilakukan dengan dua tahap yaitu pengembangan instrumen tes berbentuk esai dan pengukuran kemampuan multi representasi dan pemahaman konsep siswa. Uji validitas dilakukan untuk menguji kelayakan instrumen dan uji korelasi digunakan untuk menentukan hubungan antara kemampuan multi representasi dan pemahaman konsep siswa yang didasarkan pada data jumlah skor multi representasi dan pemahaman konsep. Hasil penelitian menunjukkan bahwa: 1) instrumen yang dikembangkan dinyatakan valid dari aspek konten dan bahasa dengan indeks Aiken sebesar 0,76 dan berdasarkan aspek konstruk dinyatakan sangat valid dengan indeks Aiken mencapai 0,86; 2) Kemampuan multi representasi siswa pada representasi verbal sebesar 43\%, representasi matematik-simbolik 32\% dan 25\% untuk representasi gambar-simbolik. Kemampuan representasi matematik-simbolik dan verbal dikategorikan dalam kategori kurang dan kemampuan representasi gambar-simbolik siswa dikategorikan sangat kurang; 3) Rata-rata pemahaman konsep siswa pada materi gerak lurus sebesar 26\%; 4)Berdasarkan uji korelasi diperoleh koefisien korelasi sebesar 0,726 yang menunjukkan bahwa kemampuan multi representasi dengan pemahaman konsep memiliki hubungan positif dan signifikan dimana jika kemampuan multi representasi siswa tinggi maka pemahaman konsep siswa juga tinggi.
\end{abstract}

Kata Kunci: Pemahaman konsep, Kemampuan multi representasi, Gerak lurus

\begin{abstract}
This study aims to analyze the profile of high school students' multi-representation ability on translation motion material measured using multi-representation based instruments and to describe the relationship between multi-representation abilities and students' conceptual understanding of translation motion material. This research was conducted on 22 students of class XI IPA at one of the SMA N 1 Sambit in the even semester of the 2020/2021 school year. The research was conducted in two steps, namely the development of an essay instrument and the measurement of students' multi-representation abilities and conceptual understanding. The validity test was conducted to test the appropriateness of the instrument and the test used to determine the relationship between multi-representation abilities and students' conceptual understanding based on the data on the number of multirepresentation scores and conceptual understanding. The results showed that: 1) the instrument developed was declared valid in terms of content and language with an Aiken index of 0.76 and based on the construct aspect declared very valid with an Aiken index of $0.86 ; 2$ ) The multi-representation ability of students in verbal representation is $43 \%$, the mathematical-symbolic representation is $32 \%$ and $25 \%$ is for image-symbolic representations. Representation ability in mathematic-symbolic and verbal were categorized in poor category and representation ability in image-symbolic representation were categorized in very poor category; 3 ) The average understanding of the concept of students on translation motion material is $26 \%$; 4) Based on the correlation test, the coefficient is 0.73 which shows that the ability of multi-representation with concept understanding has a positive and significant relationship, if students' multy representation ability is high, so students' understanding of concepts is also high.
\end{abstract}

Keywords: Conceptual understanding, Multi representation ability, Translation motion

\section{PENDAHULUAN}

Pembelajaran fisika merupakan pembelajaran yang mampu memberikan siswa kemampuan untuk menyelesaikan permasalahan fisis di kehidupan sehari-hari. Kemampuan menyelesaikan masalah dipengaruhi oleh bagaimana pemahaman siswa tentang konsep yang diberikan guru dan bagaimana siswa mempertahankan konsep tersebut untuk diaplikasikan pada permasalahan yang diberikan [1]. Dalam pembelajaran fisika, 
siswa akan dilatih untuk berpikir kritis tentang berbagai fenomena yag terjadi disekitarnya dan belajar dari fenomena tersebut. Hal ini sesuai dengan teori Piaget yang mengatakan bahwa siswa akan belajar dari pengalamannya berinteraksi dengan lingkungan, salah satu pembelajaran yang tepat untuk membelajarkan siswa lewat interaksi dengan lingkungan adalah pembelajaran fisika yang merupakan cabang dari ilmu pengetahuan alam [2].

Proses pembelajaran fisika sebaiknya dilakukan dengan menekankan dan mengembangkan konsep. Pengembangan konsep dapat dilakukan dengan perluasan konsep dan membenarkan konsep siswa yang salah sehingga siswa dapat menerapkan konsep tersebut untuk menyelesaikan masalah. Pemahaman konsep menjadi penentu dari ketercapaian tujuan pembelajaran fisika. Kesalahan dalam pemahaman konsep fisika berpotensi mempengaruhi kemampuan siswa untuk menguasai teknologi karena fisika merupakan cabang dari sains yang mempelajari segala jenis fenomena termasuk teknologi [3].

Berdasarkan hal tersebut, penting sekali menekankan pada siswa untuk menguasai konsep fisika, siswa dapat menggambarkan penguasaan konsep yang dimilikinya melalui representasi yang mereka gunakan untuk menyelesaikan suatu permasalahan [3]. Penggunaan representasi akan membantu siswa dalam memecahkan masalah yang berkaitan dengan fisika. Siswa yang memiliki kemampuan pemecahan masalah yang tinggi akan menggunakan representasi non-matematik seperti grafik, diagram dan gambar, sedangkan siswa yang kurang memiliki kemampuan pemecahan masalahnya akan menggunakan representasi matemik [3]. Menurut penelitian Kohl dan Finkelstein secara umum siswa melihat representasi matematik dan gambar sebagai sesuatu yang dominan dan berlawanan, kebanyakan dari siswa memilih salah satu diantara keduanya. Sebagian siswa terpaku pada representasi matematik tanpa memahami konsep fisika yang diterapkan dalam masalah yang diberikan, hal ini karena sistem pembelajaran yang selalu mengarahkan pemecahan dengan pendekatan matematik sehingga diperlukan sebuah tes multi representasi untuk menganalisis kemampuan multi representasi siswa [4].

Hasil prapenelitian yang dilakukan di SMA Negeri 1 Sambit menunjukkan bahwa kemampuan multi representasi siswa sebesar $31 \%$ yang artinya kemampuan multi representasi siswa masih kurang. Berdasarkan jawaban siswa pada angket yang telah diberikan, sebagian besar siswa lebih memilih menggunakan representasi matematik daripada representasi yang lain. Siswa beralasan jika penggunaan representasi matematik membuat proses pemahaman materi menjadi lebih mudah terutama ketika berhadapan dengan permasalahan fisika, siswa menganggap representasi matematis lebih mudah diterapkan dalam penyelesaian permasalahan fisika. Siswa mengungkapkan selama proses pembelajaran fisika khususnya materi gerak lurus, guru memang menyampaikan materi tidak hanya dengan satu representasi namun guru cenderung memfokuskan pada persamaan matematis. Hal ini membuat siswa cenderung terpaku dan kuat pada satu representasi namun lemah di representasi yang lain.

Dalam pembelajaran fisika digunakan lebih dari satu representasi untuk menyampaikan informasi dan mengkontruksi pengetahuan [5]. Pembelajaran dengan multi representasi memberikan beberapa cara untuk memahami suatu konsep sehingga dapat membantu siswa memahami konsep yang dipelajari[6]. Multi representasi dalam pembelajaran fisika mempunyai tiga fungsi yaitu (1)sebagai alat untuk menguraikan masalah ketika siswa membuat sketsa situasi fisis secara lengkap, (2)sebagai pokok persoalan ketika siswa diminta membuat dan menganalisis grafik dan (3)sebagai prosedur formal ketika siswa diminta menggambar diagram benda bebas sebagai awal untuk memecahkan masalah [7]. Pembelajaran multi representasi berpengaruh posistif pada kemampuan kognitif siswa dimana multi representasi mampu membantu siswa membangun suatu pemahaman yang lengkap dari berbagai bentuk penyajian informasi [6]. Multi representasi dapat menguatkan pemahaman konsep dan menambah kepercayaan diri siswa karena suatu konsep akan lebih jelas ketika disajikan dalam berbagai representasi [8].

Ada tiga jenis assesmen yang dapat digunakan untuk mengembangkan kemampuan multi representasi yaitu assesmen sumatif, assesmen formatif dan assesmen diagnostik [9]. Penguasaan konsep fisika siswa akan tepat jika diakses dengan soal multi representasi [10]. Kemampuan siswa dalam memahami suatu konsep dapat diukur dengan memperhatikan bagaimana siswa menyelesaikan permasalahan fisika berbentuk multi representasi.

Ada beberapa tipe tes yaitu pilihan ganda dan esai. Pilihan ganda merupakan tes yang paling banyak digunakan di dunia dan pada saat yang sama di nilai dan dievaluasi secara teknis [11]. Kelemahan pilihan ganda yaitu ada kesempatan untuk mendapat jawaban benar dengan menebak dan kemampuan berpikir siswa akan sulit untuk diamati, sementara tes esai dapat mengukur kemampuan berpikir kritis, originalitas dan kemampuan untuk mengorganisir dan mensintesis pengetahuan bahkan mengukur kemampuan berpikir tingkat rendah sampai tingkat tinggi. Kelebihan menggunakan tes esai adalah (1) alat 
evaluasi yang mampu membuat siswa untuk menghafalkan, memahami dan mengorganisir materi yang telah dipelajari, (2) siswa dapat mengungkapkan pemikiran masing-masing dengan menggunakan katakata sendiri, dan (3) dapat mengevaluasi berbagai kompetensi seperti mengungkapkan pendapat, berpikir kritis dan menyimpulkan.

Penelitian Ekawati menunjukan sebagian besar siswa memiliki kemampuan representasi matematis yaitu sebesar 42\%. Siswa yang ahli menggunakan representasi matematis kurang memahami makna fisika dari representasi matematis dan konsep mekanika yang diterapkan dalam kehidupan sehari-hari sementara siswa dengan kemampuan representasi verbal dan diagram dalam kategori sangat kurang yaitu mencapai $100 \%$ dan $89 \%$ dari keseluruhan jumlah sampel [9]. Hasil penelitian yang dilakukan oleh Hasbullah di SMA N 6 Kota Banda Aceh menunjukkan bahwa kemampuan multi representasi siswa pada materi gerak lurus dimana pada representasi verbal, matematis dan gambar masih rendah sedangkan pada representasi grafik dalam kategori sedang. Berdasarkan data tersebut, guru sebaiknya melakukan penilaian atau assesmen untuk mengukur tingkat kemampuan multi representasi siswa sehingga guru dapat segera melakukan evaluasi untuk pembelajaran selanjutnya [12].

Berdasarkan hasil prapenelitian dan latar belakang tersebut dilakukan penelitian analisis kemampuan multi representasi dan kaitannya dengan pemahaman konsep siswa SMA pada materi gerak lurus. Penelitian ini bertujuan untuk mendeskripsikan instrumen multi representasi yang layak digunakan sebagai pengukur kemampuan multi representasi siswa, menganalisis profil miskonsepsi siswa kelas XI IPA pada materi gerak lurus yang diukur menggunakan instrumen berbasis multi representasi berupa soal tes berbentuk esai, dan menjelaskan hubungan antara kemampuan multi representasi dengan pemahaman siswa pada materi gerak lurus.

\section{METODE PENELITIAN}

Penelitian ini merupakan jenis penelitian deskriptif dengan menggunakan metode survei. Metode survei digunakan dengan tujuan untuk mengumpulkan informasi tentang suatu peristiwa atau fakta dari populasi tertentu, dimana dalam penelitian ini adalah profil kemampuan multi representasi siswa. Penelitian dilakukan pada siswa kelas XI IPA sebanyak 22 siswa di SMA Negeri 1 Sambit pada semester genap tahun ajaran 2020/2021. Penelitian dilakukan dengan pemberian soal berbasis multi representasi dalam bentuk esai. Instrumen soal berisi subbab materi gerak lurus meliputi gerak lurus beraturan, gerak lurus berubah beraturan, dan gerak vertikal dan disesuaikan dengan level kognitif berdasarkan kurikulum 2013. Instrumen tes dinyatakan valid berdasarkan aspek validitas.
Validitas internal dilakukan oleh dua dosen ahli dengan memperhatikan aspek bahasa, isi dan konstruk. Data yang diperoleh dari validator kemudian dianalisis sesuai dengan analisis Aiken. Kevalidan instrumen didasarkan pada tabel 1 berikut [13].

Tabel 1. Kriteria Kevalidan Instrumen

\begin{tabular}{cc}
\hline Interval & Kriteria \\
\hline $0.00-0.20$ & Sangat Tidak Valid \\
$0.21-0.40$ & Tidak valid \\
$0.41-0.60$ & Cukup valid \\
$0.61-0.80$ & Valid \\
$0.81-1.00$ & Sangat valid \\
\hline
\end{tabular}

Soal tes yang diberikan sebanyak lima butir soal, siswa diminta menyajikan jawaban dari soal tersebut dalam beberapa representasi yaitu gambar, simbolik, matematik dan verbal. Jawaban siswa kemudian dianalisis berdasarkan kemampuan representasi matematik-simbolik (MS), gambar-simbolik (G-S), dan verbal (V) serta pemahaman konsep siswa. Setelah melakukan perhitungan skor kemampuan multi representasi, siswa digolongkan ke dalam empat kategori sebagai berikut.

Table 2. Kategori kemampuan multi representasi

\begin{tabular}{cc}
\hline Kategori & $\boldsymbol{\%}$ \\
\hline Sangat kurang & $0-25$ \\
Kurang & $25-50$ \\
Cukup baik & $50-75$ \\
Baik & $76-100$ \\
\hline
\end{tabular}

Skor kemampuan multi representasi dan pemahaman konsep siswa kemudian diuji menggunakan uji korelasi Product Moment Pearson dengan persamaan berikut.

$$
\mathrm{r}_{\mathrm{xy}}=\frac{\sum x y}{\sqrt{\left(\sum x^{2}\right)\left(\sum y^{2}\right)}}
$$

Uji korelasi dilakukan dengan membandingkan data jumlah skor multi representasi siswa dengan data jumlah skor pemahaman konsep siswa yang diperoleh setelah pengerjaan soal, dikatakan memiliki korelasi jika nilai koefisien korelasi mencapai $\geq 0.70$ [14].

\section{HASIL DAN PEMBAHASAN}

Hasil penelitian yang dibahas meliputi kelayakan instrumen, profil kemampuan multi representasi serta hubungan antara kemampuan multi representasi dengan pemahaman konsep siswa. Instrumen soal tes berisi lima butir soal dengan materi gerak lurus meliputi gerak lurus beraturan, gerak lurus berubah beraturan, dan 
gerak vertikal yang di setiap soalnya siswa menjawab soal dengan menggunakan representasi matematiksimbolik, gambar-simbolik dan verbal.

\section{Kelayakan Instrumen}

Berdasarkan hasil validasi oleh dua dosen ahli Jurusan Fisika Universitas Negeri Surabaya meliputi validitas bahasa, konstruk, dan isi diperoleh hasil seperti yang ditunjukan pada tabel 2 berikut.
Berdasarkan gambar 1 tersebut, setelah dilakukan uji validitas menggunakan formula Aiken diperoleh indeks Aiken untuk masingmasing aspek validitas. Indeks Aiken untuk validitas konten dan bahasa sebesar 0.76 yang menandakan bahwa instrumen valid berdasarkan konten dan bahasa. Indeks Aiken untuk validitas konstruk sebesar 0.86 yang menunjukkan bahwa instrumen yang digunakan sangat valid berdasarkan aspek konstruk intrumen.

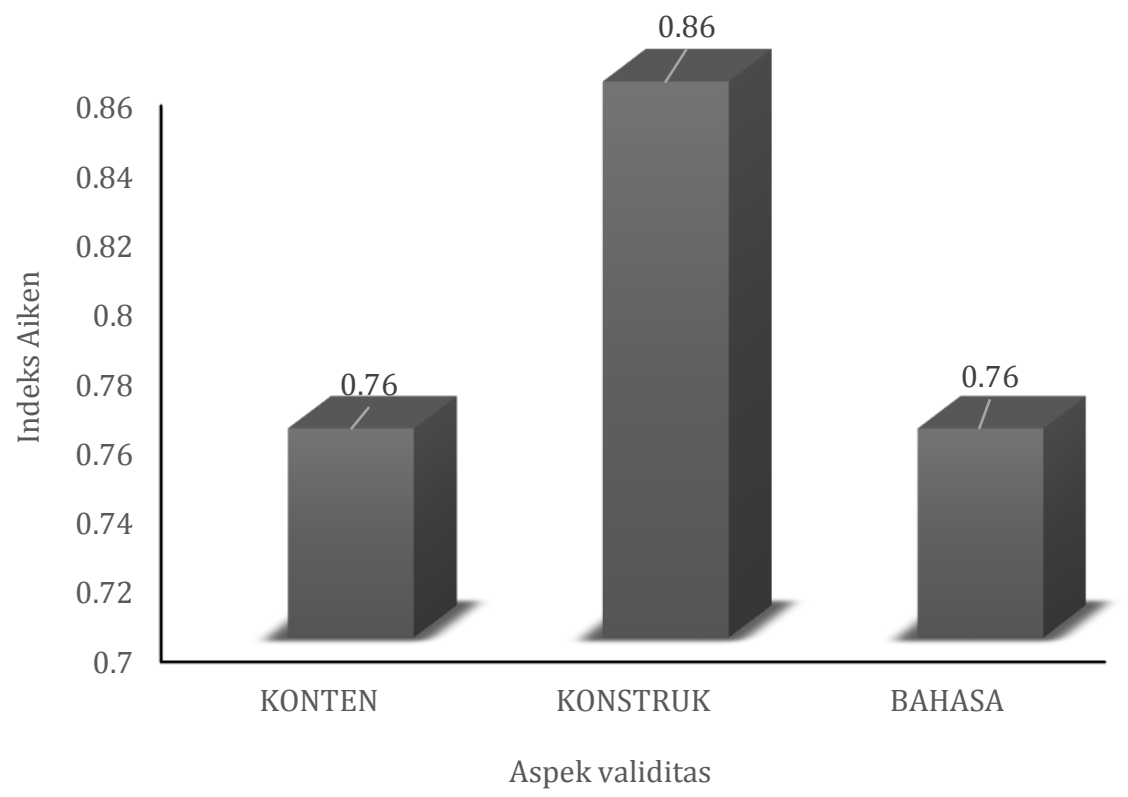

Gambar 1. Validitas instrumen

\section{Profil Kemampuan Multi Representasi}

Berdasarkan penelitian yang telah dilakukan menggunakan instrumen tes multi representasi berbentuk esai, data yang diperoleh berupa profil kemampuan multi representasi dan pemahaman konsep siswa. Hasil penelitian menunjukkan tingkat kemampuan multi representasi yang ditunjukan melalui jawaban siswa berupa representasi gambarsimbolik, matematik-simbolik dan verbal. Berikut ini merupakan profil kemampuan multi representasi (KM) siswa pada beberapa butir soal.

Pada soal representasi matematissimbolik, siswa diminta untuk menentukan nilai dari kecepatan dan kelajuan, secara matematik siswa menerapkan persamaan yang kurang benar. Kecepatan adalah perpindahan dibagi waktu dan kelajuan adalah jarak dibagi waktu namun siswa menuliskan jika persamaan matematis untuk kecepatan dan kelajuan adalah sama, begitu pula pada penerapan representasi simbolik siswa juga masih kurang, dan hal ini terjadi pada sebagian besar siswa. Berdasarkan data yang disajikan pada tabel 3 tersebut kemampuan representasi matematik-simbolik siswa mencapai $28 \%$. Kemampuan representasi matematik-simbolik seluruh siswa berkisar antara $13 \%-28 \%$.

Pada soal representasi gambar-simbolik, siswa diminta untuk menggambarkan grafik kecepatan terhadap waktu dan kelajuan terhadap waktu dari pergerakan benda. Jawaban siswa pada tabel 3 tersebut menunjukan bahwa siswa belum mampu melukiskan grafik dan menempatkan besaran fisis pada sumbu yang tepat. Siswa melakukan kesalahan dalam melukis kurva grafik dan menuliskan variabel yang tidak tepat dimana seharusnya kelajuan berada di sumbu y dan waktu di sumbu $x$ namun siswa menuliskan kecepatan di sumbu y dan kelajuan di sumbu x. Terdapat pula siswa yang salah dalam menempatkan variabel seperti waktu di sumbu y dan kelajuan di sumbu $\mathrm{x}$, selain itu penggunaan simbol besaran fisis siswa yang juga belum tepat. Ada dua jenis jawaban siswa dalam menuliskan simbol dari besaran fisis ketika melukis grafik yaitu menuliskan simbol yang salah dan menuliskan makna dari simbol tersebut. Persentase kemampuan siswa pada representasi grafik-simbolik berkisar antara 12\%-20\%. 
Tabel 3. Profil kemampuan multi representasi siswa berdasarkan jawaban yang diberikan siswa

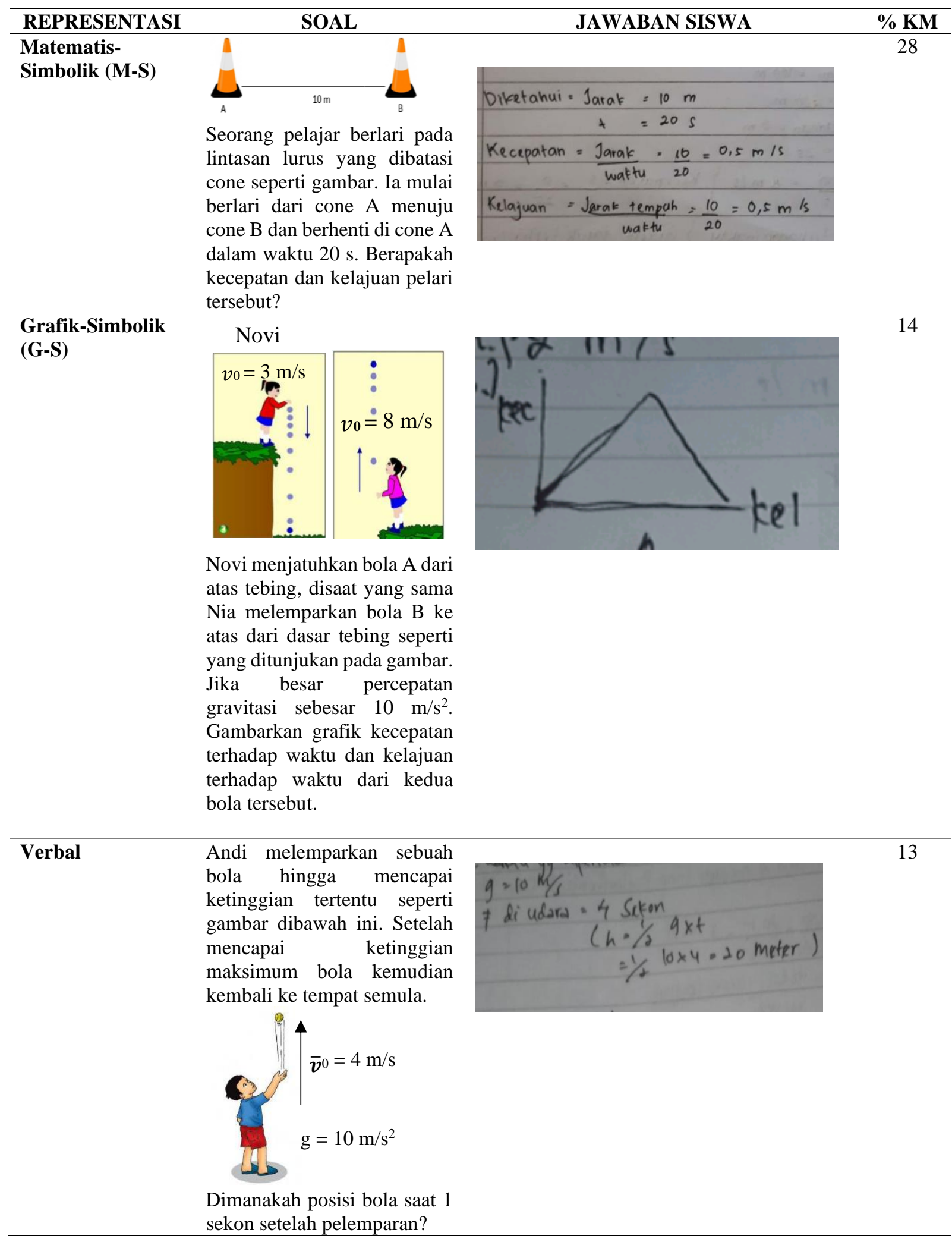

Pada soal representasi verbal siswa diminta untuk menjelaskan posisi benda $1 \mathrm{~s}$ setelah pelemparan. Sebagian besar siswa menjawab pertanyaan tersebut dengan menggunakan persamaan matematis. Posisi adalah kedudukan suatu benda berdasarkan titik acuannya, ada sebagian siswa yang menjawab menggunakan representasi matematik-verbal namun tidak 
dilengkapi dengan acuannya, siswa hanya memberikan jawaban jika bola tersebut berada di ketinggian 20 meter. Persentase kemampuan representasi verbal siswa berkisar antara 13\%-32\%. Persentase tertinggi diperoleh ketika siswa diminta untuk menjelaskan konsep kecepatan sebagai besaran vektor pada gerak vertikal ke atas dan ke bawah. Berdasarkan jawaban siswa tersebut dapat diketahui bahwa siswa masih kurang dalam menginterpretasikan ke dalam bentuk verbal, Siswa cenderung berpikir bahwa semua penyelesaian persoalan fisika harus diselesaikan dengan persamaan matematis. Rata-rata presentase tiap kemampuan representasi siswa ditunjukkan pada grafik berikut.

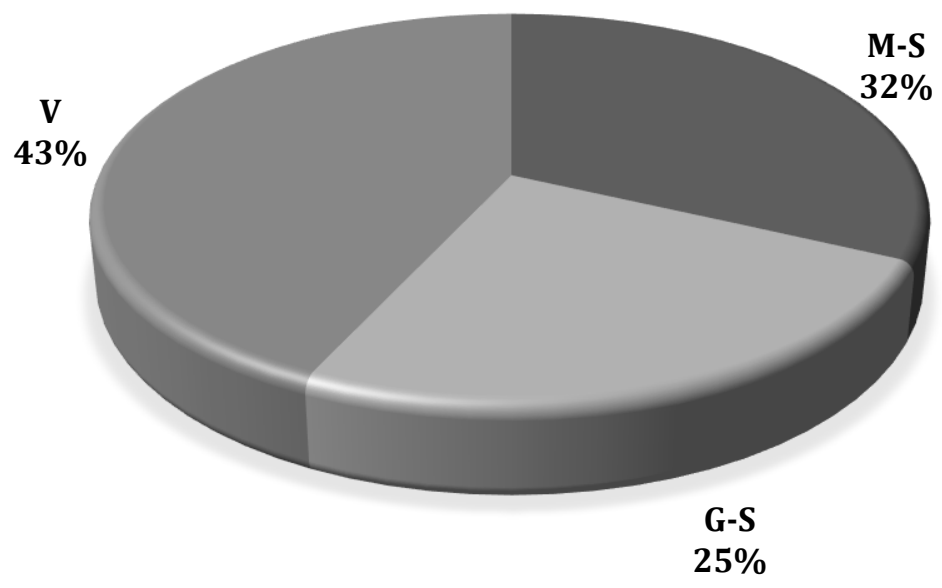

Gambar 2. Diagram kemampuan multi representasi siswa

Berdasarkan grafik tersebut, kemampuan representasi verbal lebih tinggi dibandingkan dengan representasi matematik-simbolik dan gambarsimbolik. Representasi gambar-simbolik memiliki persenntase terendah, hal ini terjadi pada indikator melukis grafik dan menganalisis grafik. Siswa masih kurang mampu dalam membedakan besaran fisis yang termasuk ke dalam besaran vektor dan besaran skalar. Ada siswa yang menganggap bahwa kurva grafik kecepatan terhadap waktu yang berada di daerah negatif menunjukan bahwa benda yang bergerak tersebut mengalami perlambatan sementara yang sebenarnya adalah benda tersebut bergerak dalam arah yang berlawanan dengan arah gerak sebelumnya. Kesulitan tersebut juga berakibat pada penulisan simbol yang masih belum tepat sehingga siswa lebih memilih menggunakan makna dari simbol daripada menuliskan simbol besaran fisis yang ingin digunakan. Hal tersebut sesuai dengan penelitian Dimas yang menemukan bahwa sebagian besar siswa memiliki kemampuan representasi grafik yang masih kurang. Kesulitan siswa ini nantinya mempengaruhi bagaimana siswa menyelesaikan permasalahan [15].

Profil kemampuan multi representasi siswa yang diperoleh kemudian digunakan untuk mengkategorikan siswa ke dalam empat kategori seperti yang terdapat pada tabel 2. Berdasarkan ratarata skor kemampuan representasi siswa diperoleh besar persentase kemampuan multi representai siswa pada tiap representasi seperti pada gambar 2. Berdasarkan persentase tersebut pada representasi matematik-simbolik dan verbal siswa masuk dalam kategori kurang dan pada representasi gambar-simbolik siswa masuk dalam kategori sangat kurang. Siswa dianggap memiliki kemampuan multi representasi namun masih melupakan beberapa hal yang penting seperti kurangnya kemampuan menerapkan simbol, kesulitan membedakan besaran vektor dan skalar, dan kesulitan menjelaskan suatu konsep fisika pada sebuah permasalahan.

Siswa cenderung kuat pada representasi matematik dan verbal namun kurang pada representasi gambar padahal fisika adalah materi yang tidak hanya dijelaskan dengan persamaan matematis namun juga menggunakan representasi gambar dan verbal sehingga konsep fisika lebih mudah disampaikan dan dipahami. Salah satu faktor penyebab kecenderungan siswa tersebut berasal dari metode pembelajaran guru yang berat ke salah satu representasi sehingga kemampuan multi representasi siswa belum berkembang dengan maksimal. Pada gambar 1 telah ditunjukan bahwa kemampuan representasi gambar-simbolik siswa paling rendah dibandingkan dengan representasi yang lain. Hal ini disebabkan karena 
selama proses penyelesaian soal siswa lebih memusatkan pada persamaan matematis apa yang harus digunakan untuk menyelesaikan soal dan bagaimana mereka harus menjelaskan jawaban mereka menggunakan representasi verbal. Kondisi tersebut sesuai dengan temuan Setyandaru yang mengungkapkan bahwa kemampuan representasi gambar yang rendah disebabkan karena siswa fokus pada penggunaan representasi matematik dan verbal [16].

Pemahaman konsep siswa diukur menggunakan intrumen yang sama dengan indikator pemahaman konsep yang berbeda pada setiap butir soal. Berdasarkan analisa yang sudah dilakukan diperoleh besar persentase pemahaman konsep ratarata siswa sebesar $26 \%$. Sebagian siswa menjawab dengan salah dan sebagian yang lain tidak memberikann jawaban. Berdasarkan jawaban yang diberikan siswa menunjukkan sebagian besar siswa belum sepenuhnya menguasai konsep besaran vektor dan skalar, siswa belum mampu menganalisis grafik, melukis grafik dan mendeskripsikan pergerakan suatu benda berdasarkan grafik pergerakan benda tersebut serta belum sepenuhnya memahami konsep kecepatan, kelajuan, perpindahan dan jarak. Ketika diminta untuk melukiskan grafik kecepatan terhadap waktu dan kelajuan terhadap waktu, siswa menggambarkan kurva grafik yang sama, begitu juga dalam melukis grafik perpindahan terhadap waktu dan jarak terhadap waktu. Hal tersebut sesuai dengan penelitian Pratiwi yang mengemukakan bahwa ketika informasi yang disajikan dalam soal berupa grafik maka siswa akan mengalami kesulitan dalam penyelesaian soal [17]. Kesulitan tersebut disebabkan oleh pemahaman konsep siswa yang masih terpotongpotong.

Pemahaman konsep yang belum sepenuhnya benar ini disebabkan salah satunya karena konsepsi awal siswa yang tidak benar. Materi gerak lurus sudah diperoleh siswa sejak SMP pada mata pelajaran IPA dan berlanjut di SMA pada mata pelajaran Fisika. Guru hanya fokus pada penguasaan penerapan persamaan matematis dan kurang menekankan pada penguasaan konsep sehingga siswa membangun konsepnya sendiri tanpa tahu apakah konsep yang dimilikinya itu benar atau salah. Konsepsi awal yang kurang benar tersebut akhirnya mempengaruhi bagaimana pemahaman konsep siswa pada pembelajaran yang lebih lanjut dan berakibat pada hasil belajar siswa. Hasil belajar yang baik diperoleh dari pemahaman konsep yang baik [18]. Konsep awal yang kurang benar dapat berakibat pada terjadinya miskonsepsi, seperti yang diungkapkan Rahayu dimana faktor penyebab miskonsepsi adalah pemahaman konsep siswa yang rendah dan penerapan metode pembejaran yang kurang tepat [19].

\section{Hubungan Kemampuan Multi Repressentasi dan Pemahaman Konsep Siswa}

Data kemampuan multi representasi dan pemahaman konsep siswa yang diperoleh kemudian diuji menggunakan uji korelasi Product Moment Pearson dengan taraf signifikansi sebesar 0.05 dan dihitung menggunakan persamaan (1). Kemampuan multi representasi sebagai variabel manipulasi disimbolkan dengan $X$ dan pemahaman konsep siswa sebagai variabel respon disimbolkan dengan Y. Nilai korelasi yang bernilai mendekati angka 1 memiliki makna bahwa korelasi antara X dan $\mathrm{Y}$ adalah searah, peningkatan $\mathrm{X}$ akan mengakibatkan peningkatan pada Y dan sebaliknya [14]. Tabel 3 berikut merupakan data jumlah skor kemampuan ulti representasi dan pemahaman konsep siswa yang digunakan untuk melakukan uji korelasi.

Tabel 3. Uji korelasi skor kemampuan multi representasi dan pemahaman konsep

\begin{tabular}{cccccccc}
\hline & $\mathrm{X}$ & $\mathrm{Y}$ & $\mathrm{x}$ & $\mathrm{y}$ & $\mathrm{x}^{2}$ & $\mathrm{y}^{2}$ & $\mathrm{xy}$ \\
\hline JML & 404 & 144 & 8 & 10 & 4223 & 76 & 422 \\
\hline
\end{tabular}

Berdasarkan uji korelasi yang dilakukan, diperoleh nilai $r_{\text {hitung }}>r_{\text {tabel }}$ dimana nilai koefisien korelasi yang diperoleh sebesar 0.726. Nilai tersebut menunjukan bahwa ada hubungan yang signifikan antara kemampuan multi representasi dengan pemahaman konsep. Hubungan yang dimaksud yaitu hubungan yang searah artinya jika kemampuan multi representasi siswa tinggi maka tingkat pemahaman konsep siswa juga tinggi dan sebaliknya. Hal ini sesuai dengan temuan Isnaini yang menyatakan bahwa terdapat hubungan hubungan yang positif antara kemampuan multi representasi dan pemahaman konsep siswa [20].

Hubungan tersebut terlihat dari persentase skor kemampuan multi representasi dan skor pemahaman konsep siswa. Siswa dengan persentase kemampuan multi representasi sebesar $24 \%$ memiliki skor pemahaman konsep sebesar $20 \%$ sedangkan siswa dengan persentase kemampuan multi representasi sebesar 39\% memiliki skor pemahaman konsep mencapai $44 \%$. Hal ini sesuai dengan temuan Hasbullah yang mengungkapkan ketika siswa diberikan pendekatan multi representasi maka kemampuan multi representasi siswa akan meningkat yang kemudian berdampak pada peningkatan pemahaman konsep siswa [12]. Guru diharapkan mampu membantu siswa untuk meningkatkan kemampuan multi representasi siswa dengan demikian tingkat pemahaman konsep siswa juga akan meningkat sesuai dengan penelitian Doyan yang menjelaskan bahwa multi representasi mempengaruhi hasil belajar siswa karena 
penyajian materi dengan berbagai format dapat meningkatkan pemahaman konsep siswa [7].

\section{KESIMPULAN}

Berdasarkan hasil analisis dari data penelitian yang diperoleh dapat disimpulkan bahwa intrumen tes yang digunakan untuk mengukur kemampuan multi representasi dan pemahaman konsep siswa layak digunakan. Kemampuan multi representasi siswa pada representasi verbal dan matematik-simbolik masuk dalam kategori kurang dengan persentase masing-masing sebesar $43 \%$ dan $32 \%$ dan pada representasi gambar-simbolik masuk dalam kategori sangat kurang dengan persentase sebesar 25\%. Kemampuan multi representasi memiliki korelasi positif dengan pemahaman konsep dengan koefisien korelasi sebesar 0.726 yang menunjukkan adanya hubungan yang signifikan antara kemampuan multi representasi dengan pemahaman konsep siswa, semakin tinggi kemampuan multi representasi maka pemahaman konsep siswa juga tinggi dan sebaliknya.

\section{DAFTAR PUSTAKA}

[1] Marlis. (2015). Analisis Profil Pemahaman Konsep dan Konsistensi Konsepsi Siswa Kelas X SMA Negeri 1 Tilatang Kamang pada Materi Fluida Statis. Prosiding Simposium Nasional Inovasi dan Pembelajaran Sains 2015. Bandung: 8-9 Juni 2015.

[2] Sufiyah, S., Wasis, W., \& Soetjipto, S. (2017). Pengembangan Perangkat Pembelajaran Model Guided Inquiry untuk Menurunkan Miskonsepsi Siswa pada Materi Optik. JPPS (Jurnal Penelitian Pendidikan Sains), 7(1), 1441-1446.

[3] Theasy, Y. (2018). Multi-representation Ability of Students on the Problem Solving Physics. In Journal of Physics: Conference Series (Vol. 983, No. 1, p. 012005). IOP Publishing.

[4] Kusumawati, I., Marwoto, P., \& Linuwih, S. (2015). Implementation Multi Representation and Oral Communication Skills in Department of Physics Education on Elementary Physics II. In AIP Conference Proceedings (Vol. 1677, No. 1, p. 040017). AIP Publishing LLC.

[5] Treagust, D.F., Reinder, D. \& Hans E. F. (2017). Multirepresentation in Physics Education. Switzerland: Springer.

[6] Widianingtiyas, L., Siswoyo, S., \& Bakri, F. (2015). Pengaruh Pendekatan Multi Representasi dalam Pembelajaran Fisika terhadap Kemampuan Kognitif Siswa SMA. Jurnal Penelitian \& Pengembangan Pendidikan Fisika, 1(1), 31-38.

[7] Doyan, A., Taufik, M., \& Anjani, R. (2018). Pengaruh Pendekatan Multi Representasi terhadap Hasil Belajar Fisika Ditinjau dari Motivasi Belajar Peserta Didik. Jurnal Penelitian Pendidikan IPA, 4(1).
[8] Suhandi, A., \& Wibowo, F. C. (2012). Pendekatan Multirepresentasi dalam Pembelajaran Usaha-Energi dan Dampak terhadap Pemahaman Konsep Mahasiswa. Jurnal Pendidikan Fisika Indonesia, 8(1).

[9] Ekawati, R., Setiawan, A., Wulan, A. R., \& Rusdiana, D. (2019). The use of Classroom Assessment Based on Multi-Representation Ability in Mechanics Concept. In Journal of Physics: Conference Series (Vol. 1157, No. 3, p. 032061). IOP Publishing.

[10] Murtono, M. (2018). The Multyrepresentation Test as Assessment Authentic For Learning Prospective Teacher Physics. Integrated Lab Journal, 4(2), 189-198.

[11] Istiyono, E. (2019, June). The Developing and Calibration of PhysEDiTHOTS Based on IRT and IQF for Students' HOTS Diagnostic. In Journal of Physics: Conference Series (Vol. 1233, No. 1, p. 012038). IOP Publishing.

[12] Hasbullah, H., Halim, A., \& Yusrizal, Y. (2018). Penerapan Pendekatan Multi Representasi terhadap Pemahaman Konsep Gerak Lurus. Jurnal IPA \& Pembelajaran IPA, 2(2), 69-74.

[13] Kurniawati, D., Muhlis, M., \& Makhrus, M. (2020). Validitas Multimedia Interaktif pada Materi Kemagnetan Berbasis Indikator Penguasaan Konsep dan Kemampuan Berpikir Kreatif. Jurnal Pijar Mipa, 15(5), 527-532.

[14] Ananda, R., \& Fadhli, M. (2018). Statistik pendidikan: teori dan praktik dalam pendidikan. Medan: CV. Widya Puspita.

[15] Dimas, A., Suparmi, A., Sarwanto, \& Nugraha, D. A. (2018). Analysis Multiple Representation Skills of High School Students on Simple Harmonic Motion. In AIP Conference Proceedings (Vol. 2014, No. 1, p. 020131). AIP Publishing LLC.

[16] Setyandaru, T. A., Wahyuni, S., \& aristya Putra, P. D. (2017). Pengembangan Modul Pembelajaran Berbasis Multirepresentasi pada Pembelajaran Fisika di SMA/MA. Jurnal Pembelajaran Fisika, 6(3), 223-230.

[17] Pratiwi, Y. M., Suyudi, A., \& Zulmasula, Z. (2017). Identifikasi Kesulitan Siswa SMA pada Materi Gerak Lurus. Jurnal Riset Pendidikan Fisika, 2(2).

[18] Irwandani, I. (2015). Pengaruh Model Pembelajaran Generatif terhadap Pemahaman Konsep Fisika Pokok Bahasan Bunyi Peserta Didik Mts Al-Hikmah Bandar Lampung. Jurnal Ilmiah Pendidikan Fisika Al-Biruni, 4(2), 165-177. 
[19] Rahayu, P., \& Hariyono, E. (2019). Profil Penguasaan Konsep Siswa pada Sub Materi Gerak Jatuh Bebas dengan Menggunakan Four Tier Diagnostic Test. Inovasi Pendidikan Fisika, 8(2).

[20] Isnaini, M., \& Ningrum, W. P. (2018). Hubungan Keterampilan Representasi terhadap Pemahaman Konsep Kimia Organik. Orbital: Jurnal Pendidikan Kimia, 2(2), 12-25. 